\title{
Will Inequality Affect Growth? Evidence from USA and China since
}

\section{0}

\author{
Yongqing Wang ${ }^{1}$ \\ ${ }^{1}$ Department of Business and Economics, University of Wisconsin-Waukesha, Waukesha, WI, USA \\ Correspondence: Yongqing Wang, Department of Business and Economics, University of Wisconsin-Waukesha, 1500 \\ North University Drive, Waukesha, Wisconsin 53188, USA. E-mail: yongqing.wang @uwc.edu
}

Received: October 8, 2017

Accepted: October 28, 2017

Online Published: November 16, 2017

doi:10.5430/rwe.v8n2p1

URL: https://doi.org/10.5430/rwe.v8n2p1

\begin{abstract}
Income inequality may hinder economic growth is a widespread concern. The results from previous literature are mixed. Although both USA and China is an excellent case study by itself, it is even interesting to compare them given they are the two largest economies in the world, and yet completely different from each other. We employ annual data from 1980 to 2012 and apply cointegration to study the effects of income inequality on real GDP per capita and real GDP of both USA and China. We also include the exchange rate into the model to examine possible effects of depreciation on growth. The main findings are: first, depreciation does not affect the growth of USA. Second, depreciation promotes growth of China in the short-run, but may hurt its growth in the long-run. Third, income inequality will hurt growth of USA in the short-run, while it encourages its growth in the long-run. Finally, income inequality may promote growth of China in both short-run and long-run.
\end{abstract}

Keywords: income inequality, growth, cointegration, USA and China

JEL Classification: F41, O11, O15, O40

\section{Introduction}

The income inequality in most developed and developing countries has increased, especially since 1980 . Consequently, income inequality has attracted a lot of economists' attention. Different issues such as the measurement, the determinants, the causes, and the trend of income inequality have been examined extensively using cross-sectional data and/or time series data.

Among these issues, high income inequality may harm growth is a widespread concern although most economists believe certain inequality is necessary for an economy to grow. But the effect of high inequality on growth is debatable. Inequality can promote or impair growth for different reasons. An IMF (International Monetary Fund) Staff Discussion Note by Ostry, Berg and Tsangarides (2014) gives an excellent review of previous literature. As summarized by Ostry, Berg and Tsangarides (2014), inequality may promote growth because it provides incentives for innovation and entrepreneurship, potentially increases saving and investment, and enables some individuals in poor countries to begin to rise economically by accumulating the minimum needed to start a business or getting a good education. On the other hand, lower income families could suffer in their physical and economic health, political or economic instability could be exacerbated, and the social consensus needed to adjust to shocks and sustain growth may be significantly limited. The inequality may affect growth for other reasons that are not described in Ostry, Berg and Tsangarides (2014). For example, the income inequality may promote growth if it increases productivity by encouraging labors to put in more effort in production. Inequality may lower consumer demand since the rich are more unlikely to spend additional money compared to the middle class and the poor, and thus impair growth. But when the rich spend less, the saving will increase. With higher saving, higher investment is a possibility and it is one of the reasons that the inequality may have positive influence on growth. However, with higher saving, the interest rate will be lower, which will drive up the asset price and encourage consumers to borrow in order to purchase the asset. This will make it harder for the central banks to administrate the economy and may generate the economic instability, which may hinder economic growth.

Nevertheless, Ostry, Berg and Tsangarides (2014) concluded that inequality is a robust and powerful determinant of growth and "the resulting growth may be low and unsustainable". 
Obviously, a wide variety of studies have tried to address the effect of inequality on growth, but the results are rather mixed. Hence, it is important to test the effects of income inequality on growth at a country level. Each country is different and has its own specific characteristics. Therefore, the effects of income inequality on growth of different countries could be different.

The effects of income inequality on growth of USA and China are especially interesting to study. USA and China are currently the largest two economies in the world based on the nominal gross domestic product (GDP). The income inequality in both countries has increased quite dramatically since 1980. However, besides the high nominal GDP and inequality, USA and China are distinct and they share very few things in common, which will be briefly discussed in Section 2.

The purpose of this study is to examine the effects of income inequality on growth of USA and China by employing time-series data from 1980 to 2012. 1980 is chosen since the income inequality of both USA and China increased tremendously since 1980. 2012 is selected because it is the last year that the income inequality data is available from World Income Inequality Database (WIID3.3) by United Nations University World Institute for Development Economics Research (UNU-WIDER). To this end, we compare a few main Macro data of USA and China in the study period in section 2. Section 3 introduces the model and explains the estimation method. Section 4 presents the results, while Section 5 concludes.

\section{USA and China in Comparison}

\section{1) Growth in USA and China from 1980 to 2012}

USA is a well-developed economy and has been one of the most powerful economies in the world for a very long period of time. On the contrary, China is an emerging developing country. China was a planned economy before 1978 with very low national income and per capita income. But China has experienced rapid growth since economic reform in 1978 and now it is the second largest economy in the world.

From 1980 to 2012, the growth rate of USA is relatively modest, while the growth rate of China was quite high. The average growth rate of USA is $2.7 \%$ with the maximum at $7.3 \%$ and minimum at $-2.8 \%$. The average growth rate of China is $9.9 \%$ with the maximum at $15.2 \%$ and minimum at $3.8 \%$. The growth rate of USA and China from 1980 to 2012 is showed in Figure 1. The high growth rate in China is due to the economic reform in China since 1978 and the initial low income to start with.

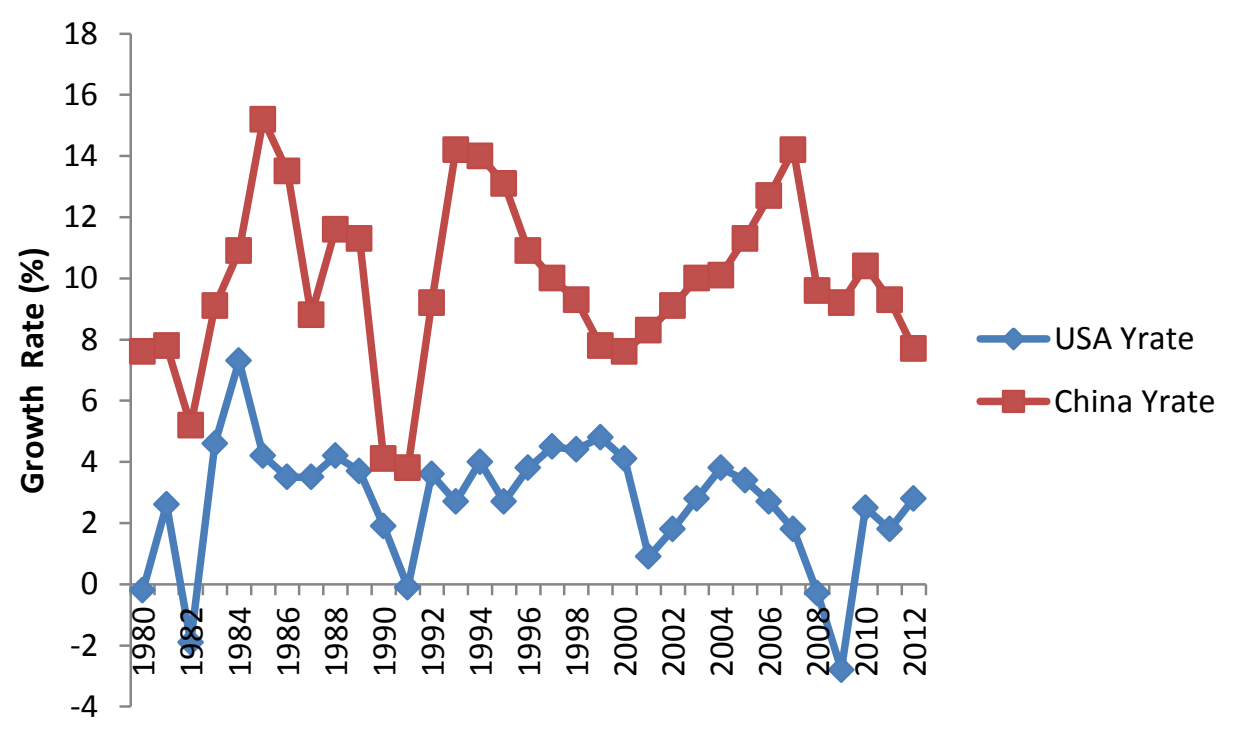

Figure 1

Although China's growth rate was quite high, USA's nominal GDP, real GDP, and real GDP per capita were much higher than the corresponding ones in China by 2012. Based on the World Bank's data, USA's nominal GDP was 
about two times as large as Chinese nominal GDP in 2012. But in 2012, USA's real GDP was about 5 times as large as China's real GDP, while USA's real GDP per capita was about 20 times as large as China's real GDP per capita. Even the current data indicates China's real GDP per capita is much less than USA's. The nominal GDP, real GDP, and real GDP per capita of USA and China from 1980 to 2012 are displayed in Figure 2, 3 and 4, respectively.

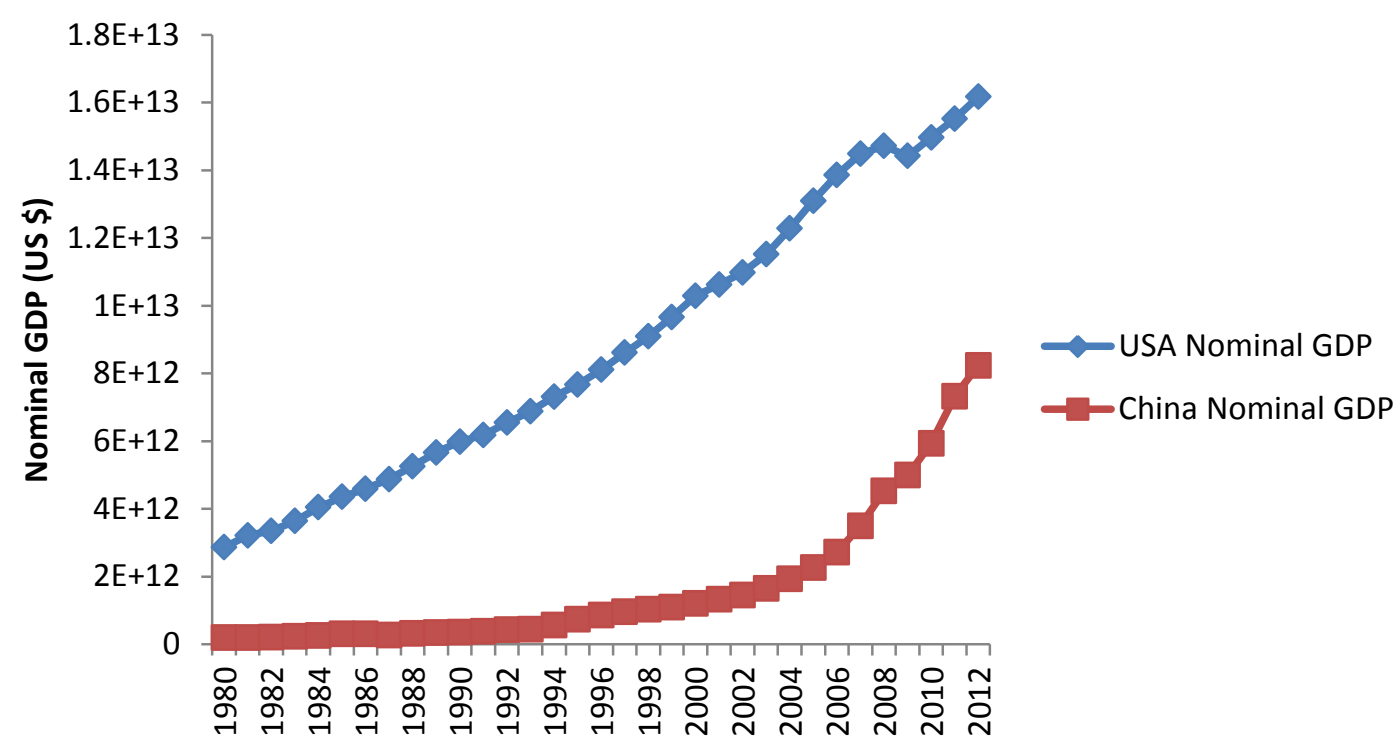

Figure 2

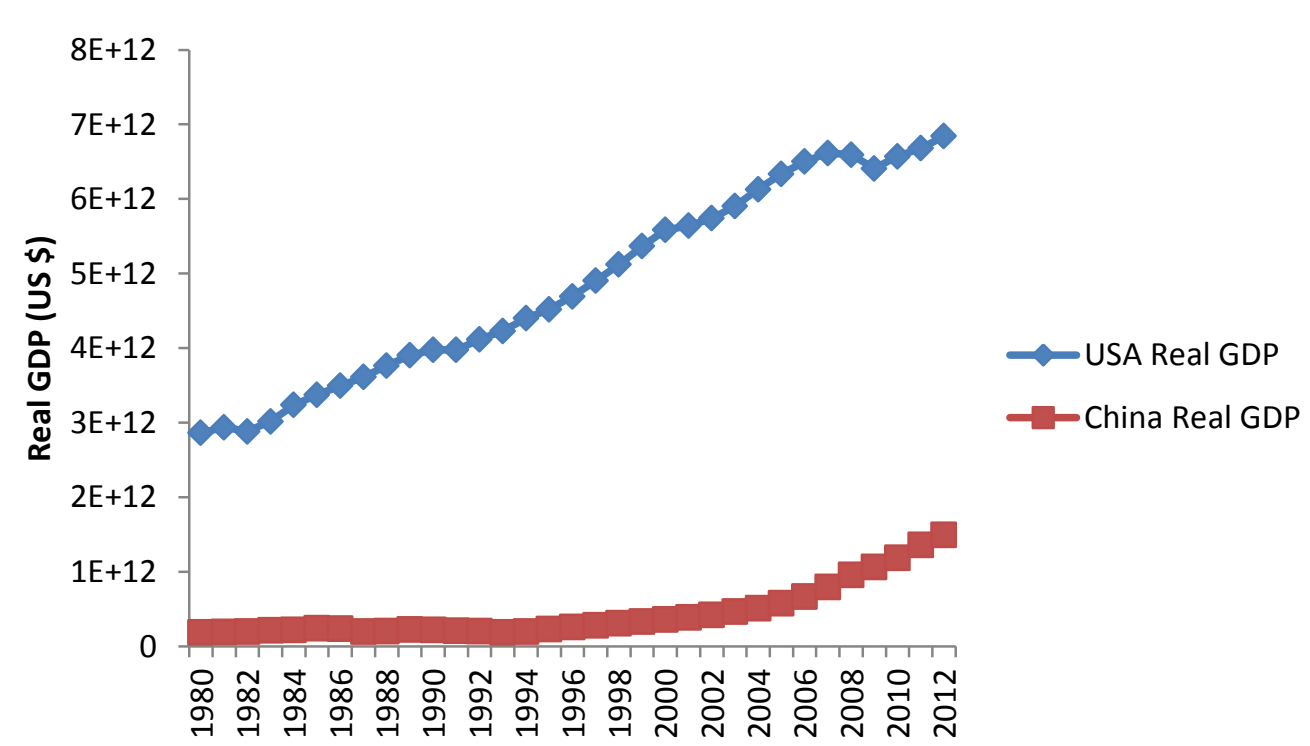

Figure 3 


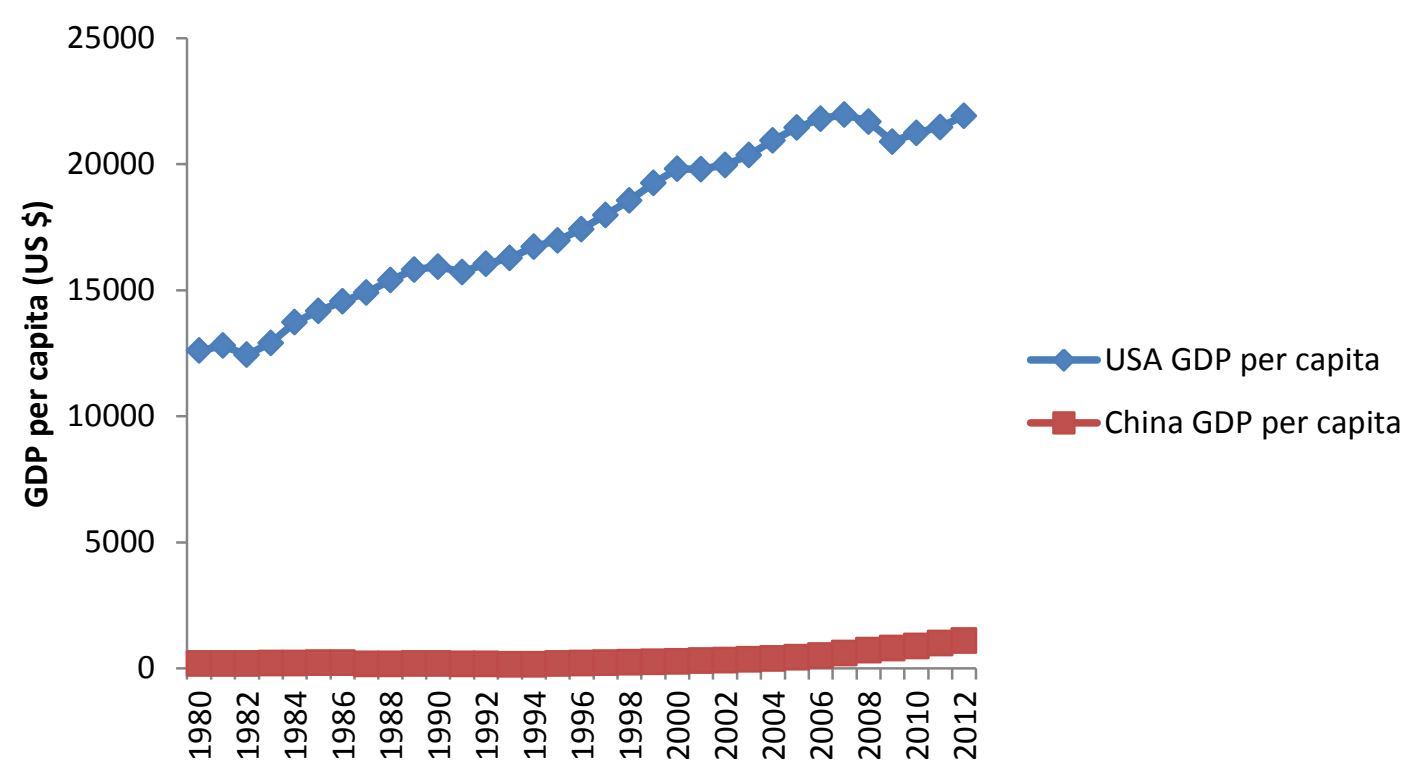

Figure 4

2) Trade in USA and China since 1980

Both USA and China are large open economy. But the trade data is not the same. In order to compare, we look at the exports and imports as percentage of GDP. From 1980 to 2012, USA exports on average counted about $10 \%$ (ranging from $7 \%$ to $14 \%$ ) of its GDP, while USA imports on average counted about $12 \%$ (ranging from 9\% to 17\%) of its GDP. USA exports were less than its imports and had trade deficit for most years in the period we study. In 1980, Chinese exports were only about $6 \%$, while imports were only about $6.6 \%$ of its GDP. Since then, both Chinese exports and imports have increased dramatically. By 2012, Chinese exports counted 27\% of its GDP and Chinese imports counted 25\% of its GDP. From 1980 to 2012, Chinese exports on average counted about $20 \%$ of its GDP (ranging from 6\% to 39\%) while Chinese imports on average counted about 18\% of its GDP (ranging from 6.6\% to $32 \%$ ). China had trade surplus for the majority years in the period of 1980 to 2012 .

Clearly, compared to USA, China's exports and imports took up a larger share of its GDP. We define openness of a country as the sum of exports and imports as percentage of its GDP. Then, from 1980 to 2012, the openness of USA on average was about $22 \%$, ranging from $17 \%$ to $31 \%$. The openness of China on average was about $39 \%$, ranging from $12.6 \%$ to $70 \%$. The high openness of China is because China had used exports to promote growth and Chinese economy had grown tremendously.

USA exports and imports, separately, as percentage of GDP are illustrated in Figure 5; Chinese exports and imports, separately, as percentage of its GDP are showed in Figure 6; and the openness of both countries is displayed in Figure 7. 


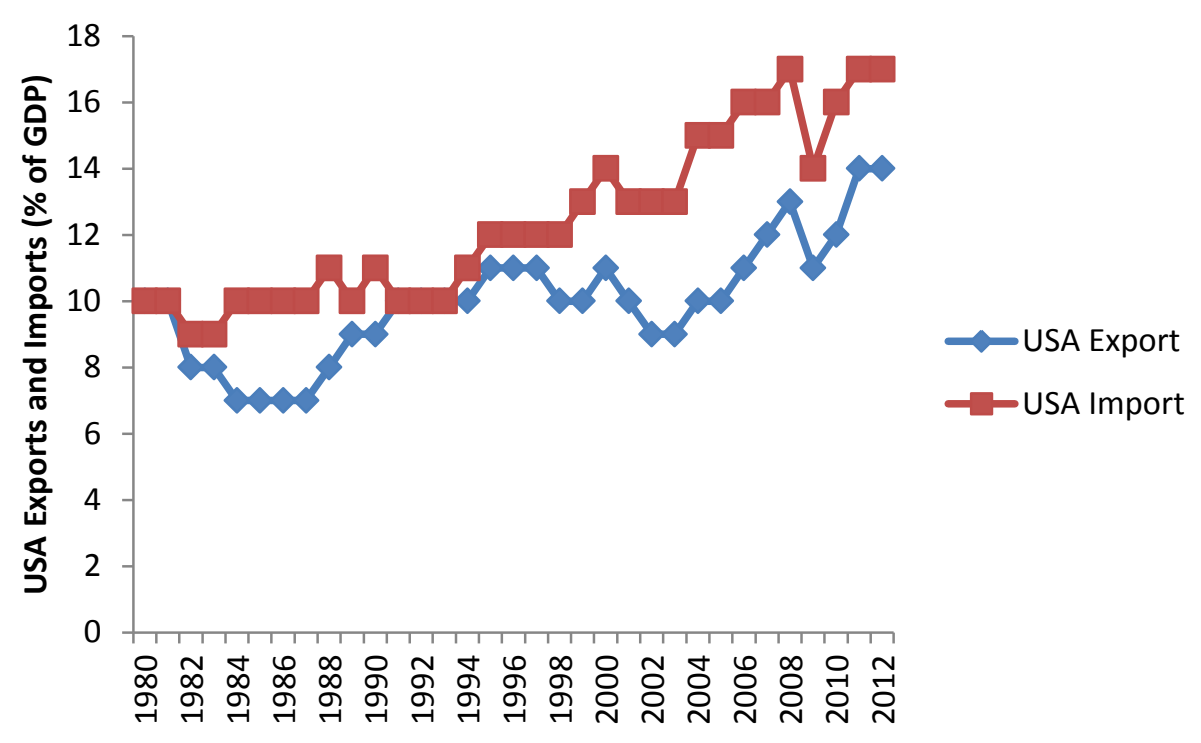

Figure 5

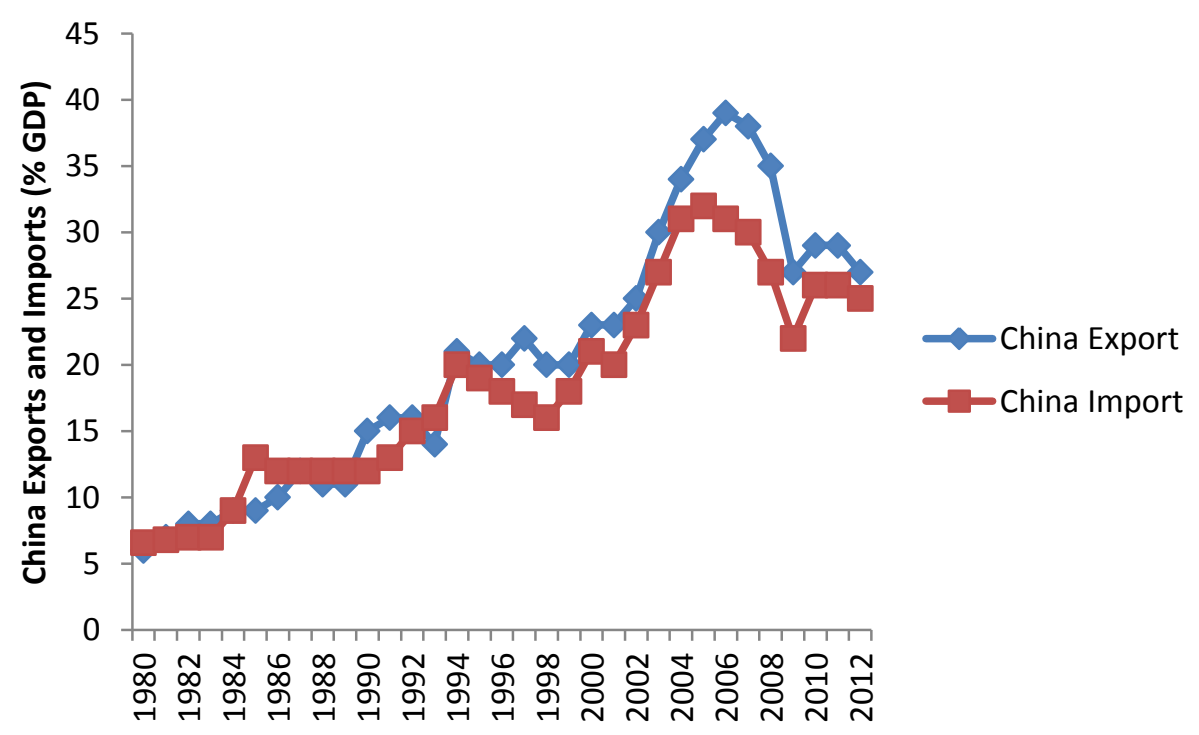

Figure 6 


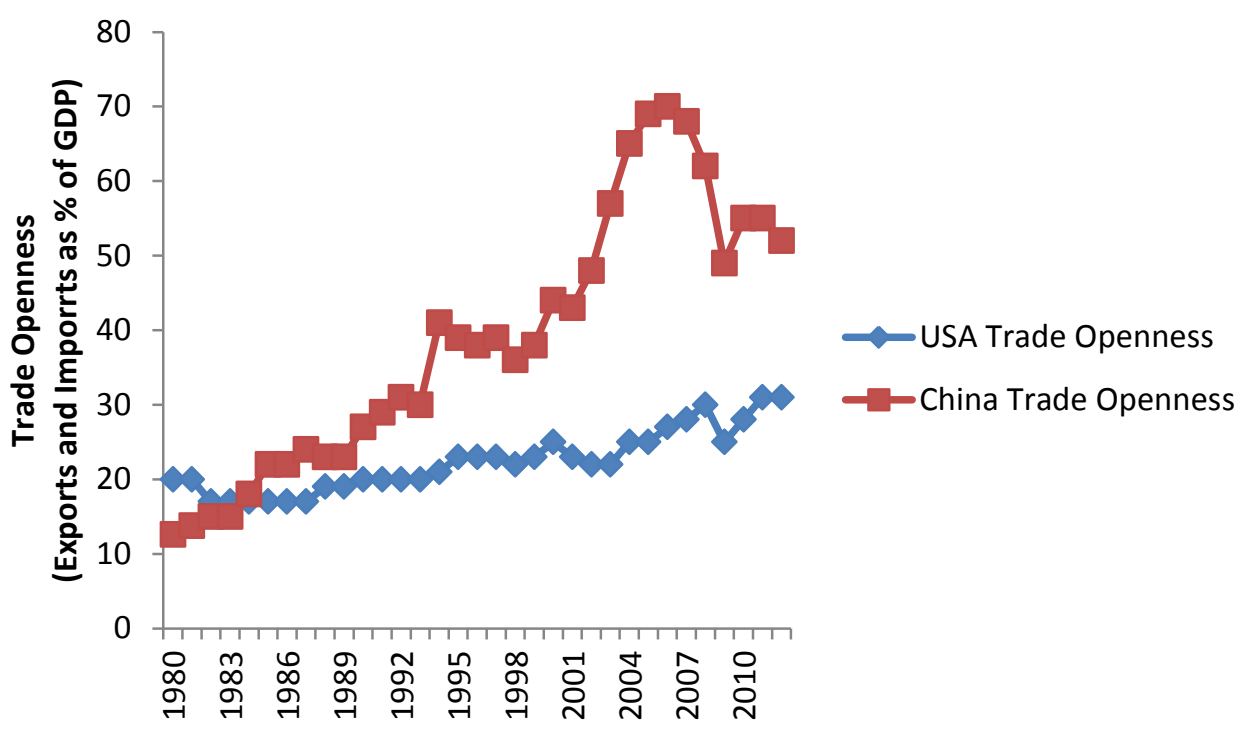

Figure 7

3) Exchange rate in USA and China

The real effective exchange rate index (year $2000=100$ ) for both USA and China is demonstrated in Figure 8.

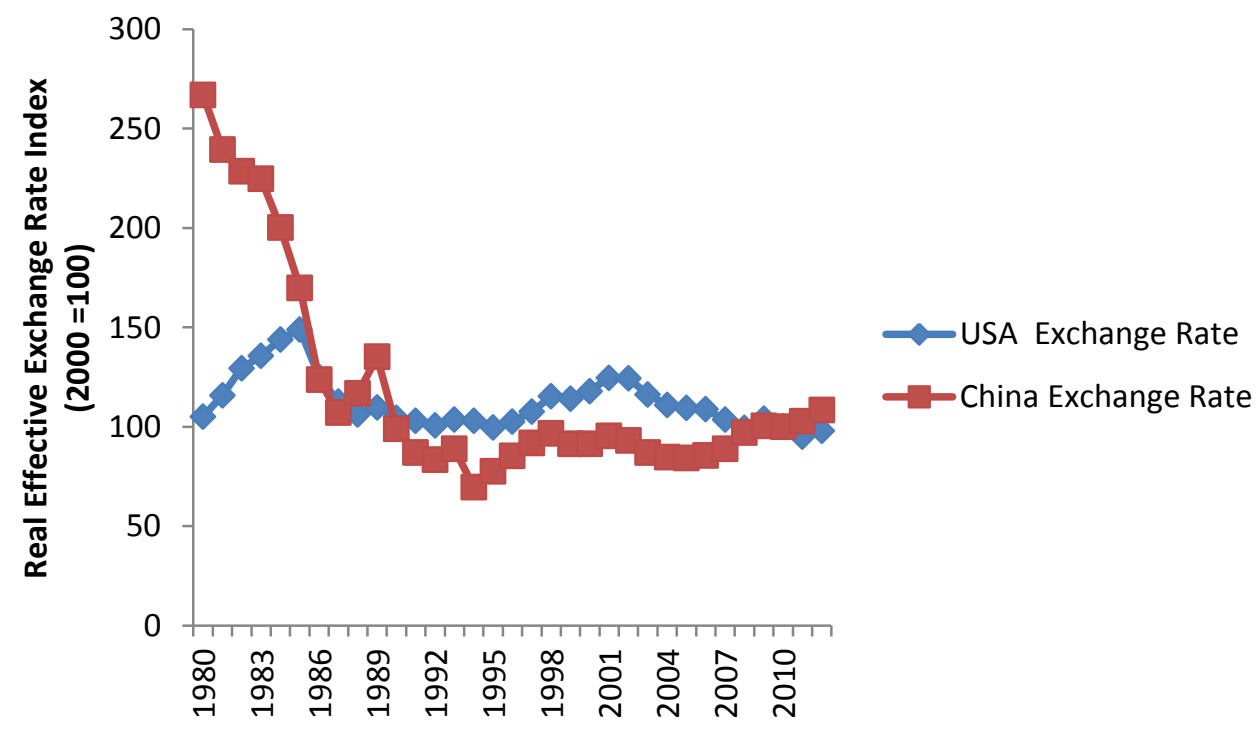

Figure 8

USA adopts floating exchange rate. Overall, the real effective exchange rate of USA was relatively stable. In the period of 1980 to 2012, the maximum of real effective exchange rate index was at 149 in 1985; minimum was at 95.1 in 2011; and the average was about 99.

China had fixed exchange rate before July 2005. In July of 2005, China discarded the fixed exchange rate and moved to a "managed floating exchange rate regime". The new exchange rate system allows Chinese exchange rate to float within certain percentage based on market supply and demand with reference to a basket of currencies. The maximum of the real effective exchange rate for China was 266.8 in 1980; the minimum was at 69.6 in 1994; and the average was about 115. 


\section{4) Income Inequality in USA and China}

The data of income inequality in USA and China are also different. For USA, the income inequality, measured by Gini index, increased steadily from 40.3 in 1980 to 47.7 in 2012 . However, Gini index was only about 32 in China in 1980 , but it gradually increased to 49.1 in 2008 , and then slightly decreases to 47.4 in 2012 . The data of Gini index is illustrated by the following Figure 9. Obviously, China started with lower income inequality. But the income inequality in China fluctuated more and had risen at a faster pace than in the United States.

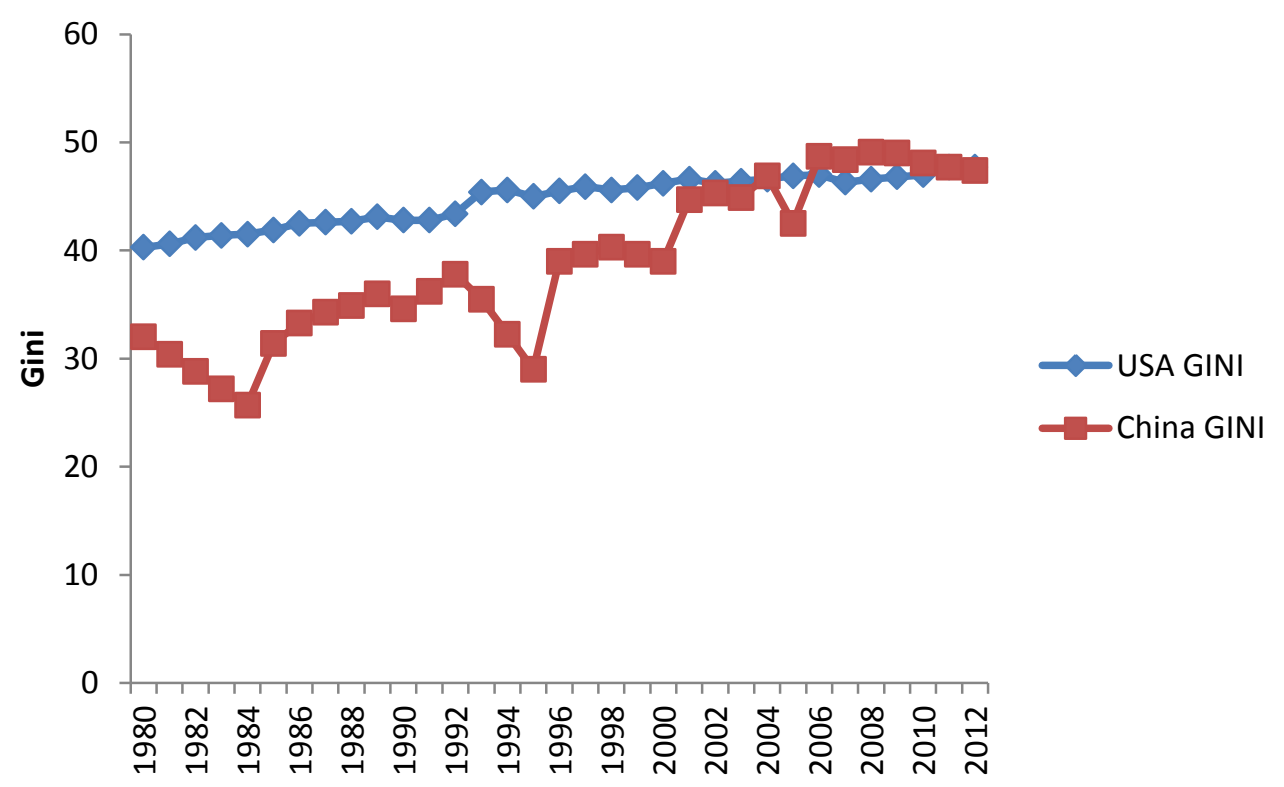

Figure 9

\section{The Model and Method}

Given the purpose of this study, we consider the following model outlined by equation (1):

$$
\operatorname{Ln} Y_{t}=a+b \operatorname{Gini}_{t}+c \operatorname{LnEX} X_{t}+\varepsilon_{t}
$$

where $\mathrm{Y}$ is the national income; Gini is one of the most common measurements for income inequality, and EX is the real effective exchange rate index $(2000=100)$. In this study, we use two measurements for national income: real GDP per capita and real GDP. The data definition and resources are in the Appendix.

Regarding the sign of the coefficients of Gini, it could be either positive or negative for the reasons that have been discussed in Section 1.

Exchange rate is also included into the model in order to test the possible effect of depreciation on growth. But the effect of depreciation on growth is also unclear. When a currency depreciates, it promotes exports because the exports become cheaper to foreigners, while it discourages imports because the imports become more expensive. If the value of exports increases because a fall in the price leads to larger increase in the quantity, a depreciation of a currency will boost national income. However, a fall in the price of exports will cause only a small rise in quantity if demand for exports is price inelastic. Thus, the value of exports may actually fall. If this is the case, a depreciation of a currency will hurt the national income. Note that in this study, exchange rate is the real effective exchange rate index and a decrease in the value of real effective exchange rate implies a depreciation of this currency. Therefore, if the coefficient of exchange rate is negative, it indicates depreciation will promote national income. If the estimation of the coefficient for exchange rate is positive, it indicates the depreciation will hurt the national income.

Equation (1) states the long-run relationship among the variables. We incorporate the short-run dynamic of equation (1) 
in order to carry out the testing procedure and study the possible effect in the short run. Following Pesaran et al. (2001), it takes following form:

$$
\begin{aligned}
\Delta \operatorname{Ln} Y_{t}=\alpha+\sum_{k=1}^{n} \beta_{0, k} \Delta & \operatorname{LnY_{t-k}}+\sum_{k=0}^{n} \beta_{1, k} \Delta \operatorname{Gini}_{t-k}+\sum_{k=0}^{n} \beta_{2, k} \Delta \operatorname{LnEX}_{t-k} \\
& +\delta_{0} \operatorname{LnY}_{t-1}+\delta_{1} \operatorname{Gini}_{t-1}+\delta_{2} \operatorname{LnEX}_{t-1}+\mu_{t}
\end{aligned}
$$

The null hypothesis is no cointegration $\left(\delta_{0}=\delta_{1}=\delta_{2}=0\right)$ and the alternative hypothesis is $\delta_{0} \neq \delta_{1} \neq \delta_{2} \neq 0$. Pesaran et al. (2001) introduces a technique that does not require pre-unit root testing. In order to justify cointegration among the variables in (2), Pesaran at al. (2001) calculated a new set of critical values for F-test. Assuming all variables are integrated of order one, upper bound of critical values is computed, while assuming all variables are integrated of order zero, lower bound of critical values is calculated. If F-test statistic is less than the lower bound of critical values, the null hypothesis can't be rejected. If the F-test statistic lies between the bounds, the test is inconclusive. Only when F-test is above the upper bound, the null hypothesis is rejected, suggesting cointegration among the variables in the equation.

\section{The Empirical Results}

Annual data from 1980 to 2012 were employed to carry out the empirical analysis. In the empirical tests, we first impose 6 lags on each first differenced variable in equation (2) and carry out the F-test. Table 1 reports the results of the calculated F-tests for USA, and Table 2 reports the results of the calculated F-tests for China. 95\% upper bound and lower bound of critical values are also reported in the Tables 1 and 2.

Table 1. The result of F-tests for USA

\begin{tabular}{lccccc}
\hline \multicolumn{5}{c}{ USA } \\
\hline $\begin{array}{l}\text { Dependent } \\
\text { Variable }\end{array}$ & $\begin{array}{l}\text { Calculated } \\
\text { F-test }\end{array}$ & Optimal lags & $\begin{array}{l}\text { F-test at } \\
\text { Optimal lags }\end{array}$ & $\begin{array}{l}\text { 95\% Lower } \\
\text { Bound }\end{array}$ & $\begin{array}{l}\text { 95\% Upper } \\
\text { Bound }\end{array}$ \\
\hline $\begin{array}{l}\text { Real GDP per } \\
\text { Capita }\end{array}$ & 5.9531 & $(6,6,4)$ & 11.0831 & 4.3807 & 5.5719 \\
\hline Real GDP & 6.0267 & $(6,6,5)$ & 14.7326 & 4.3807 & 5.5719 \\
\hline
\end{tabular}

Table 2. The result of F-tests for China

China

\begin{tabular}{lccccc}
\hline $\begin{array}{l}\text { Dependent } \\
\text { Variable }\end{array}$ & Calculated & Optimal lags & $\begin{array}{l}\text { F-test at } \\
\text { Optimal lags }\end{array}$ & $\begin{array}{l}\text { 95\% Lower } \\
\text { Bound }\end{array}$ & $\begin{array}{l}\text { 95\% Upper } \\
\text { Bound }\end{array}$ \\
\hline $\begin{array}{l}\text { Real GDP per } \\
\text { Capita }\end{array}$ & 1.2496 & $(6,6,6)$ & 24.1698 & 4.3807 & 5.5719 \\
\hline Real GDP & 0.7955 & $(6,6,6)$ & 23.3902 & 4.3807 & 5.5719 \\
\hline
\end{tabular}

From Table 1, for USA, it is clear that the calculated F tests are greater than the upper bound critical values whether the dependent variable is real GDP per capita or real GDP, suggesting cointegraton among the variables. From Table 2, cointegration among the variables for China is rejected since the calculated F-tests are less than the $95 \%$ lower bound of critical values. However, followed by Bahmani-Oskooee and Wang (2007), we regard the above results as preliminary results because the lags are selected by random. We continue with our empirical tests by choosing the appropriate number of lags on each variable according to Akaike Information Criterion (AIC). This means AIC is applied to select the optimum number of lags for each variable in equation (2) after imposing maximum of 6 lags on each first differenced variable in (2). 
The optimal lags and F-tests with optimal lags for USA are also reported in Table 1, while the ones for China are reported in Table 2. For both USA and China, no matter the dependent variable is real GDP per capita or real GDP, the F-test with optimal lags are all above the $95 \%$ upper bound critical values, indicating cointegration among the variables.

Given the objectives of this paper, we report short-run estimates of Gini in Table 3, short-run estimates of exchange rate in Table 4, while long-run results in Table 5.

Table 3. The short-run Coefficient Estimates of Gini for USA and China

\begin{tabular}{lcccc}
\hline \multicolumn{5}{c}{ Short-run Coefficient Estimates of Gini } \\
\hline & USA & USA & CHINA & CHINA \\
& Real GDP & Real GDP & $\begin{array}{l}\text { Real GDP } \\
\text { per Capita }\end{array}$ & Real GDP \\
& per Capita & & $0.0084^{*}$ & $0.0085^{*}$ \\
& 0.0089 & 0.0057 & {$[0.029]$} & {$[0.022]$} \\
\hline dGini & {$[0.334]$} & {$[0.538]$} & $0.0314^{*}$ & $0.0335^{*}$ \\
& $-0.0581^{* *}$ & $-0.0693^{* *}$ & {$[0.031]$} & {$[0.018]$} \\
\hline dGini1 & {$[0.001]$} & {$[0.000]$} & 0.0210 & $0.0234^{*}$ \\
& $-0.0509^{*}$ & $-0.0623^{* *}$ & {$[0.075]$} & {$[0.044]$} \\
\hline dGini2 & {$[0.002]$} & {$[0.000]$} & 0.0113 & 0.0129 \\
& $-0.0451^{* *}$ & $-0.0533^{* *}$ & {$[0.175]$} & {$[0.112]$} \\
\hline dGini3 & {$[0.003]$} & {$[0.001]$} & $0.0124^{*}$ & $0.0133^{*}$ \\
& $-0.0241^{*}$ & $-0.0284^{* *}$ & {$[0.040]$} & {$[0.026]$} \\
\hline dGini4 & {$[0.011]$} & {$[0.003]$} & 0.0034 & 0.0038 \\
& $-0.0244^{* *}$ & $-0.0278^{* *}$ & {$[0.197]$} & {$[0.153]$} \\
\hline
\end{tabular}

Note: * indicates $5 \%$ significance. $* *$ indicates $1 \%$ significance.

Table 4. The short-run Coefficient Estimates of Exchange Rate for USA and China

\begin{tabular}{lcccc}
\hline \multicolumn{5}{c}{ Short-run Coefficient Estimates of Exchange Rate } \\
\hline & USA & USA & CHINA & CHINA \\
& Real GDP & Real GDP & $\begin{array}{l}\text { Real GDP } \\
\text { per Capita }\end{array}$ & Real GDP \\
& per Capita & & $-0.5240^{*}$ & $-0.5423^{*}$ \\
& -0.1968 & $-0.2608^{*}$ & {$[0.020]$} & {$[0.012]$} \\
\hline dLnEX & {$[0.129]$} & {$[0.037]$} & $0.3830^{* *}$ & $0.3688^{* *}$ \\
& -0.0753 & -0.0313 & {$[0.000]$} & {$[0.000]$} \\
\hline dLnEX1 & {$[0.315]$} & {$[0.716]$} & -0.1406 & $-0.1745^{*}$ \\
& -0.1252 & -0.0992 & {$[0.060]$} & {$[0.024]$} \\
\hline dLnEX2 & {$[0.064]$} & {$[0.137]$} & 0.0147 & -0.0237 \\
& $-0.1598^{*}$ & $-0.1570^{*}$ & {$[0.816]$} & {$[0.714]$} \\
\hline dLnEX3 & {$[0.033]$} & {$[0.018]$} & $-0.3119^{* *}$ & $-0.3165^{* *}$ \\
& NA & -0.0794 & {$[0.001]$} & {$[0.001]$} \\
\hline dLnEX4 & & {$[0.319]$} & $-0.2908^{* *}$ & $-0.3031^{* *}$ \\
& NA & NA & {$[0.006]$} & {$[0.004]$} \\
\hline dLnEX5 & & & & \\
\hline
\end{tabular}

Note: $*$ indicates $5 \%$ significance. $* *$ indicates $1 \%$ significance. 
Table 5. The Long-run Coefficient Estimates for USA and China

\begin{tabular}{lcccc}
\hline \multicolumn{5}{c}{ Long-run Coefficient Estimates } \\
\hline Model & USA & USA & CHINA & CHINA \\
& Real GDP & Real GDP & $\begin{array}{l}\text { Real GDP } \\
\text { per Capita }\end{array}$ & Real GDP \\
& per Capita & & $0.0802^{* *}$ & $0.0849^{* *}$ \\
& $0.0769^{* *}$ & $0.1165^{* *}$ & {$[0.000]$} & {$[0.000]$} \\
\hline Gini & {$[0.000]$} & {$[0.000]$} & $3.0662^{* *}$ & $2.7852^{* *}$ \\
& 0.0417 & -0.0333 & {$[0.009]$} & {$[0.005]$} \\
\hline EX & {$[0.647]$} & {$[0.781]$} & $-11.2507^{*}$ & $10.7575^{*}$ \\
& $6.1810^{* *}$ & $24.2413^{* *}$ & {$[0.024]$} & {$[0.011]$} \\
\hline
\end{tabular}

Note: * indicates $5 \%$ significance. $* *$ indicates $1 \%$ significance.

From Table 3, the estimations of Gini for USA and China are quite different. For USA, the majority of the coefficients for Gini in the short-run are negative and significant, which means income inequality hurt USA economy in the short-run. But for China, the coefficients for Gini in the short-run are all positive, and about half of the coefficients are significant. It is the evidence that income inequality may promote growth for developing countries such as China, while it may harm growth for developed countries such as USA in the short-run.

From Table 5, on contrary to the short-run results, the estimations of the coefficient for Gini for both USA and China in the long-run are quite consistent. The coefficients for Gini are all positive and significant, indicating the inequality will improve both real GDP per capita and real GDP in the long-run. Thus, eventually, income inequality may stimulate growth. The results contradict the findings in Tian (2012), Ostry, Berg, and Tsangarides (2014), and Petersen, and Schoof (2015), but it is consistent with Kaldor (1957), Lazear and Rosen (1981), and Risso, and Sánchez Carrera (2012). However, the effect is moderate based on current study. For USA, the coefficient of Gini in the long-run is 0.0769 when real GDP per capita is the dependent variable, while it is 0.1165 when real GDP is the dependent variable. For China, the coefficient of Gini in the long-run is 0.0802 when real GDP per capita is the dependent variable, while it is 0.0849 when the dependent variable is real GDP.

From Table 4, most of the coefficients of exchange rate for USA are not significant in the short-run, indicating the effect of depreciation on the national income is trivial. Consequently, it is not surprised to observe the estimations of coefficient of real exchange rate for USA in the long-run are also not significant.

But for China, the results are quite different compared to USA. From Table 4, most of the coefficients for exchange rate in the short-run are negative and significant. It indicates the depreciation of exchange rate (or the decrease in the value of real effective exchange rate) has improved China's trade balance and thus improved national's income in the short-run. From Table 5, the coefficients of exchange rare in the long-run for China are all positive and significant, indicating the depreciation will harm Chinese real GDP per capita and real GDP in the long-run. This may because Chinese exchange rate is controlled largely by Chinese government and it is not completely market-oriented even after China moved to the managed floating exchange rate regime.

\section{Conclusion}

In the present study, we employ annual data from 1980 to 2012 to study the effects of income inequality on growth of both USA and China. We include the exchange rate into the model in order to examine possible effects of depreciation on growth. The cointegration exists among the variables in the model that we study.

Although depreciation does not affect much of the growth of USA, the effect of depreciation on Chinese growth is significant. Possibly, this is because USA has floating exchange rate and the depreciation is moderate. Consequently, it does not affect much of the USA growth. On contrary, the exchange rate in China is under more control by its government. The degree of depreciation is much more severe compared to USA. From our results, the effect of depreciation on Chinese growth is positive in the short-run, but it is negative in the long-run. This may be the evidence that the negative effects will show in the long-run when the exchange rate is manipulated. One policy implication is: although China may take the advantage of depreciation to promote exports and growth in the short-run, the authority 
should investigate the effects of depreciation on growth in the long-run and consider adopting floating exchange rate completely.

The effects of income inequality on growth are distinct for USA and China. For USA, it seems that income inequality hurt the short-run growth, but it encourages long-run growth. USA is a well-developed country and GDP per capita is high. Inequality may impair growth in the short-run because the rich spend less additional money compared to the middle class and the poor. However, saving will increase when the rich spend less. With higher saving, higher investment is a possibility and it may be the reason that inequality in USA will promote growth in the long-run. For China, income inequality encourages growth both in the short-run and in the long-run. China is a developing economy and can easily benefit from inequality for the reasons such as inequality provides incentives for innovation, investment, higher productivity, and enables some people in poor countries to rise economically. It suggests the developing countries could consider appropriate income inequality in order to promote growth. Further, it is good that the long-run effects of income inequality on growth of real GDP per capita and real GDP of both USA and China are all positive, suggesting income inequality possibly encourages growth in the long-run. But it is still vital to investigate the other effects of income inequality on the society such as Kenworthy, L. (2016) to fully address the problem of income inequality.

\section{References}

Bahmani-Oskooee, M., \& Y. Wang. (2007). How stable is the Demand for Money in China?. Journal of Economic Development, 32, 21-33. Retrieved from http://www.jed.or.kr/full-text/32-1/32-1-2.pdf

Dabla-Norris, E., K. Kochhar, N. Suphaphiphat, F. Ricka, \& E. Tsounta. (2015). Causes and Consequences of Income Inequality: A Global Perspective, IMF (International Monetary Fund) Staff Discussion Note, SDN/15/13. Retrieved from https://www.imf.org/external/pubs/ft/sdn/2015/sdn1513.pdf

Kaldor, N. (1957). A model of Economic Growth. The Economic Journal, 67(268), 591-624 https://doi.org/10.2307/2227704

Lazear, E. P., \& S. Rosen. (1981). Rank-Order Tournaments as Optimum Labor Contracts. Journal of Political Economy, 89(5), 841-64. https://doi.org/10.1086/261010

Kenworthy, L. (2016). Is Income Inequality Harmful? The Good Society. Retrieved from lanekenworthy.net

Ostry, J. D., A. Berg, \& C. G. Tsangarides. (2014). Redistribution, Inequality, and Growth. IMF (International Monetary Fund) Staff Discussion Note, SDN/14/02. https://doi.org/10.5089/9781484352076.006

Pesaran, H. M., Y. Shin, \& R. J. Smith. (2001). Bounds Testing Approaches to the Analysis of Level Relationships. Journal of Applied Econometrics, 16, 289-326. https://doi.org/10.1002/jae.616

Petersen, T., \& U. Schoof. (2015). The Impact of Income Inequality on Economic Growth, Future Social Market Economy, Impulse \# 2015/05. $\quad$ Retrieved from http://www.bertelsmann-stiftung.de/fileadmin/files/BSt/Publikationen/GrauePublikationen/Impulse__2015-05 _income_inequality_and_growth.pdf

Risso, W. A., \& E. J. Sánchez Carrera. (2012). Inequality and economic growth in China. Journal of Chinese Economic and Foreign Trade Studies, 5(2), 80-90. https://doi.org/10.1108/17544401211233453

Tian, Y. (2012). The Effect of Income Inequality on Economic Growth in China. Economics \& Business Journal: $\begin{array}{llll}\text { Inquiries } \quad \text { \& } & \text { Perspectives, } & \text { 150-157. } & \text { Retrieved }\end{array}$ http://www.nebeconandbus.org/journal/EBJIP2012Tian.pdf

\section{Appendix}

\section{Data Definition and Sources}

Y: real GDP or real GDP per Capita. The real term is calculated from the nominal term and GDP deflator. The nominal GDP for both USA and China are from the "World Bank". The GDP per capita at current prices for both USA and China are also from the "World Bank". The GDP deflator $(1980=100)$ is calculated according to the "inflation rate based on GDP deflator" from the World Bank.

Gini: Income Inequality, which is from World Income Inequality Database (WIID3.3) by United Nations University World Institute for Development Economics Research (UNU-WIDER)

EX: Real Effective Exchange Rate Index $(2000=100)$, which is from the "World Bank". 